\title{
Estimation of regional genetic parameters for mortality and 305-d milk yield of US Holsteins in the first 3 parities
}

\author{
K. Tokuhisa, ${ }^{*}$ S. Tsuruta, ${ }^{*}$ A. De Vries, $†$ J. K. Bertrand, ${ }^{* 1}$ and I. Misztal ${ }^{*}$ \\ *Department of Animal and Dairy Science, University of Georgia, Athens 30602 \\ †Department of Animal Sciences, University of Florida, Gainesville 32611
}

\begin{abstract}
Several research reports have indicated increasing dairy cow mortality in recent years. The objectives of this research were to characterize the phenotypic differences in mortality in the first 3 parities across 3 regions of the United States to estimate the heritability of mortality of Holstein cows across regions and parities, and to estimate genetic and environmental correlations between milk yield and mortality across parities and regions. Dairy Herd Information (DHI) milk yield and mortality data were obtained from 3 different US regions: the Southeast (SE), Southwest (SW), and Northeast (NE). A total of $3,522,824$ records for the first 3 parities were used: 732,009 (SE), 656,768 (SW), and 2,134,047 (NE) from 1999 to 2008. Cows that received a termination code of 6 - "Cow died on the dairy; downer cows that were euthanized should be included here"-were given a mortality score of 2 (dead), whereas all other codes were assigned a mortality score of 1 (alive). Average annual mortalities in the first 3 parities across regions ranged from 2.2 to $7.2 \%$, with mortality frequency increasing with increasing parity across all regions and with the SE having the highest mortality frequency. For genetic analysis, a 2-trait (305-d milk yield and mortality) linear-threshold animal model that fitted fixed effects of herd-year (for 305-d milk yield), cow age, days in milk (in month classes), month-of-termination, and random effects of herd-year (for mortality), animal, and residual was implemented. The model was used to estimate variance components separately for each region and parity. Heritability estimates for mortality were similar for all regions and parities, ranging from 0.04 to 0.07. Genetic correlations between mortality and 305-d milk yield across the first 3 parities were $0.14,0.20$, and 0.29 in SE; $-0.01,0.01$, and 0.31 in SW; and 0.28 , 0.33 , and 0.19 in NE. We detected an adverse genetic relationship between milk production and mortality; however, the moderate magnitudes of the genetic corre-
\end{abstract}

Received November 8, 2013.

Accepted March 15, 2014.

${ }^{1}$ Corresponding author: jkbert@uga.edu lations suggest that indices that include both milk yield and mortality could be effective in identifying sires that would provide opportunities for minimizing death loss even when selecting for increased milk yield.

Key words: mortality, parity, region, US Holstein

\section{INTRODUCTION}

In the dairy industry, production traits such as milk, protein, and fat yields have been recognized as the most economically important traits, and therefore animals have been selected mainly for these traits (Miglior et al., 2005). As a result, a $16 \%$ increase in milk yield was obtained from 2003 to 2012 in the US milk cow population (USDA-NASS, 2013).

However, recent increases in mortality are a concern to dairy producers (Pinedo et al., 2010). Miller et al. (2008) analyzed a sample of herds from a national data set that was edited to exclude any records of mortality before the first test day and reported that dairy cow death frequency increased from $1.96 \%$ in 1996 to $4.63 \%$ in 2005. In 2007, annual cow mortality of $1.5 \%$ was estimated in the beef industry, whereas an annual cow mortality of $5.7 \%$ was reported in the dairy industry (USDA-APHIS, 2007, 2010).

Herd or regional differences that influence mortality include climate, nutrition, prevalence of diseases, and management. Because many of these factors are confounded and may differ across region, proper management is required to lower mortality within each herd or region. McConnel et al. (2008) has examined many herd management factors associated with dairy cow mortality. Several states within the United States have combinations of high heat and humidity during certain times of the year that can lead to heat stress conditions in high-producing dairy cows. Bohmanova et al. (2008) reported that states within the southeastern United States had a much higher frequency of test days where there was moderate to severe heat stress compared with those in the northeastern United States. West (2003) has reported that heat stress can cause body temperature to increase, leading to health problems, including death. Vitali et al. (2009) reported that high humidity 
Table 1. Distribution of 305-d milk yield and mortality records across parity and regions

\begin{tabular}{|c|c|c|c|c|c|c|}
\hline Region & \multicolumn{2}{|c|}{ First parity } & \multicolumn{2}{|c|}{ Second parity } & \multicolumn{2}{|c|}{ Third parity } \\
\hline Southeast & 278,526 & 293,494 & 241,878 & 255,821 & 170,664 & 182,694 \\
\hline Northeast & 866,700 & 883,887 & 711,211 & 733,904 & 492,026 & 516,256 \\
\hline
\end{tabular}

and temperature caused higher cow mortality due to heat stress. Currently, indirect selection to lower the risk of cow mortality is provided by selection on productive life (Cole et al., 2010). Productive life is included in the net merit formula, which is used for ranking dairy bulls and semen purchases by dairy farmers.

The objectives of this research were to characterize the phenotypic differences in mortality across regions and parity, to estimate heritability of mortality of Holstein cows in the first 3 parities in 3 US regions using DHI termination codes, and to estimate the genetic and environmental correlations between milk yield and mortality across parities and regions.

\section{MATERIALS AND METHODS}

\section{Data}

No animal care and use protocol was necessary for this research project because all the records used were field data. Dairy Herd Information data that contained records from 1999 to 2008 were obtained from the USDA Animal Improvement Programs Laboratory (Beltsville, MD). Lactation records of cows that had at least one test-day record, that were from parity $\leq 3$, and that had a termination or culling code were retained for analysis. Termination or culling codes included death (including downer cows that were euthanized), locomotion problems, poor production, reproduction problems, mastitis or high SCC, udder problems, other or not specified reasons, lactation with or without abortion, and selling for dairy purposes. For mortality analysis, cows with the termination code 6-"Cow died on the dairy; downer cows that were euthanized should be included here"-were assigned a code of 2 , and cows that had other termination codes were assigned a code of 1 . A total of 3,522,824 mortality and 305-d milk yield records in the first 3 parities in 3 regions were available for analysis. Table 1 presents the distribution of records across parities and regions. The 305-d milk yield records were standardized to 305-d and for age of cow (mature equivalent) using DHI adjustment procedures. Southeast (SE) data consisted of 732,009 records and included the following states: North Carolina, South Carolina, Georgia, Florida, Tennessee, Alabama, Mississippi, Arkansas, and Louisiana. Southwest (SW) data consisted of 656,768 records and included the states of Oklahoma, Texas, New Mexico, and Arizona. Finally, the Northeast (NE) data consisted of 2,134,047 records from Maine, New Hampshire, Vermont, Massachusetts, Rhode Island, Connecticut, and New York.

\section{Calculations for Phenotypic Trends}

To describe the seasonal pattern of mortality, monthly mortality frequencies were calculated within region and parity with SAS software (SAS Institute, 2008). The mortality frequency for any month within a region and parity was the number of animals that received a termination code of death or euthanasia due to downer cow syndrome within that month expressed as a percentage of all cows present within each parity and region. The annual mortality within a parity and region can then be obtained by summation of the monthly mortality frequencies.

\section{Models for Genetic Analysis}

To estimate genetic parameters, the following 2-trait linear-threshold animal model was used for 305-d milk yield and mortality:

$y_{i j k l m}=H Y_{i}+M O T_{j}+A G E_{k}+D I M_{l}+A N I_{m}+e_{i j k l m}$,

where $y_{i j k l m}=$ observations of 305 -d milk yield and mortality (binary; alive $=1$ or dead $=2$ ); $H Y_{i}=$ fixed (random) effect of herd year for 305-d in milk yield (mortality); $M O T_{j}=$ fixed effect of month of termination; $A G E_{k}=$ fixed effect of age of a cow; $D I M_{l}=$ fixed effect of DIM (in month classes); $A N I_{m}=$ random animal genetic effect; and $e_{i j k l m}=$ random error.

Covariances of genetic $(\mathrm{G})$, herd-year (HY), and residual $(R)$ effects are given below:

$$
\begin{gathered}
V(\mathbf{G})=\left[\begin{array}{cc}
\sigma_{305}^{2} & \sigma_{305, m} \\
\sigma_{m, 305} & \sigma_{m}^{2}
\end{array}\right], \\
V(\mathbf{H Y})=\left[\begin{array}{cc}
0 & 0 \\
0 & \sigma_{H Y}^{2}
\end{array}\right],
\end{gathered}
$$




$$
V(\mathbf{R})=\left[\begin{array}{cc}
\sigma_{305}^{2} & \sigma_{305, m} \\
\sigma_{m, 305} & \sigma_{m}^{2}
\end{array}\right],
$$

where subscript 305 indicates 305 -d milk yield, and $m$ indicates mortality.

The Gibbs-sampling program THRGIBBS1F90 (Tsuruta and Misztal, 2006), allowing the combining of linear and categorical traits in a single analysis, was used to estimate (co)variance components and was run separately for each region and parity. The number of iterations was set to 100,000 . The first 10,000 samples were discarded as burn-in, and every 10th sample was kept thereafter. The model was fit separately for each parity within a region, with results in the second and third parities affected by selection. A model considering all parities could not be run successfully. Post-Gibbs analysis by the POSTGIBBSF90 (Tsuruta and Misztal, 2006) program was conducted to obtain posterior distribution statistics for verification of the parameter estimates.

\section{RESULTS AND DISCUSSION}

\section{Phenotypic Trends for Mortality Frequency}

Figures 1, 2, and 3 provide the trends for monthly mortality frequency for each parity within region. Annual mortality frequencies were $3.3,4.8$, and $7.2 \%$ in SE; 2.4, 3.3, and 5.0\% in SW; and 2.2, 3.7, and $5.4 \%$ in NE for the first, second, and third parities, respectively. Across all regions, mortality increased as parity increased, with the SE region having the largest change between the first and third parity (3.9\%) and the SW region having the smallest $(2.7 \%)$. Pinedo et al. (2010) analyzed over 3.5 million records of Holstein cows east of the Mississippi River and found that mortality was similar for parity 1 and 2 cows, but increased in both the third and fourth parities. It is well known that milk production increases from the first parity to the third. McConnel et al. (2008) reported that greater rolling herd average milk production was associated with greater levels of mortality. Aguilar et al. (2009) reported that susceptibility to heat stress in the first 3 lactations increased as parity increased, which may explain some of the increased death loss with increasing parity during the summer months.

Generally, the SE region had higher mortality frequencies over all months compared with the NE and SW regions; however, the NE and SW regions had similar trends for mortality. Regional differences in mortality frequency were also found by Smith et al. (2000), who examined DHI data for the year 1998 and found that occurrences of death in the South, Mid-South, and

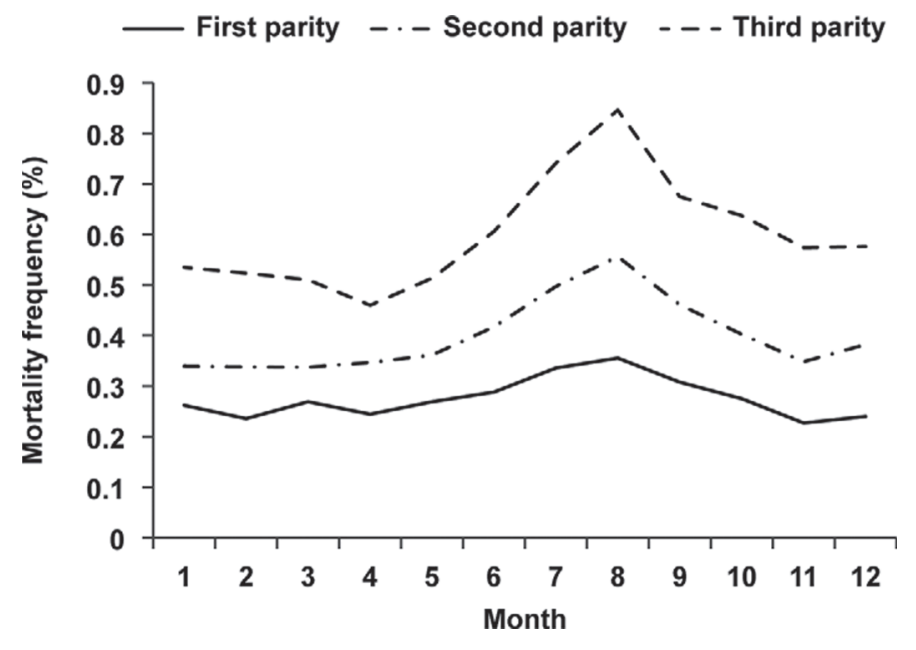

Figure 1. Monthly mortality frequencies for 3 parities in the Southeast region of the United States.

North were $7.7,7.0$, and $5.9 \%$, respectively. McConnel et al. (2008) reported that herds in the West, Midwest, and Southeast had greater levels of cow mortality than herds in the Northeast. Several factors might explain why the SE region had higher cow mortality. Dechow et al. (2012) examined sire PTA used in Pennsylvania herds with adverse cow survival ( $>4 \%$ cow mortality frequency and $>7.1 \%$ for the frequency of cows exiting the herd before $60 \mathrm{~d}$ postcalving) versus those herds with favorable cow survival (those with $<4.0$ and $<7.1 \%$, respectively, for the 2 traits). They found that the PTA of sires for SCS were much higher in herds with adverse cow survival compared with herds with favorable cow survival. McConnel et al. (2008) found increased risk of cow mortality when the herd had a high percentage

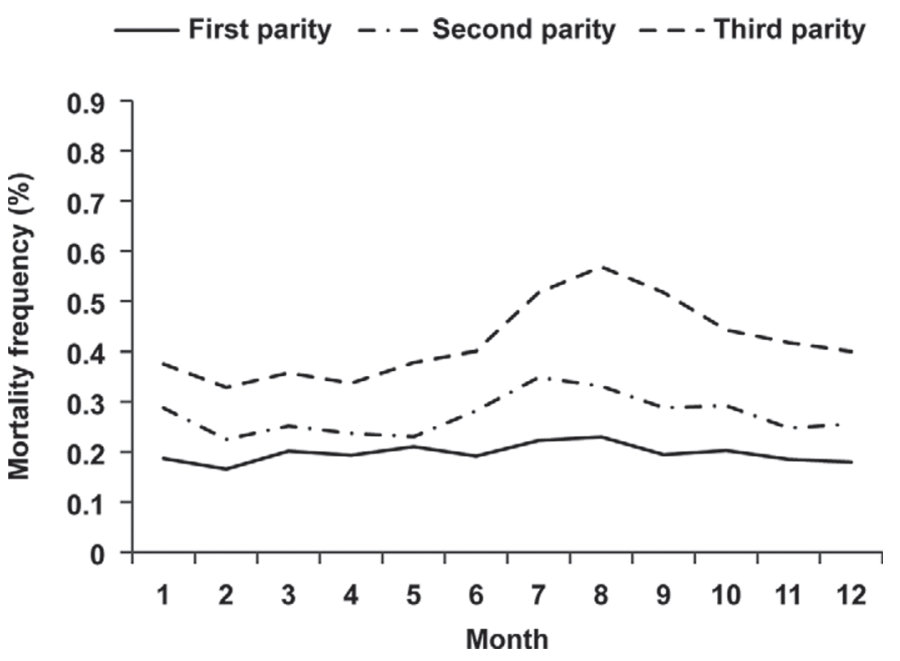

Figure 2. Monthly mortality frequencies for 3 parities in the Southwest region of the United States. 


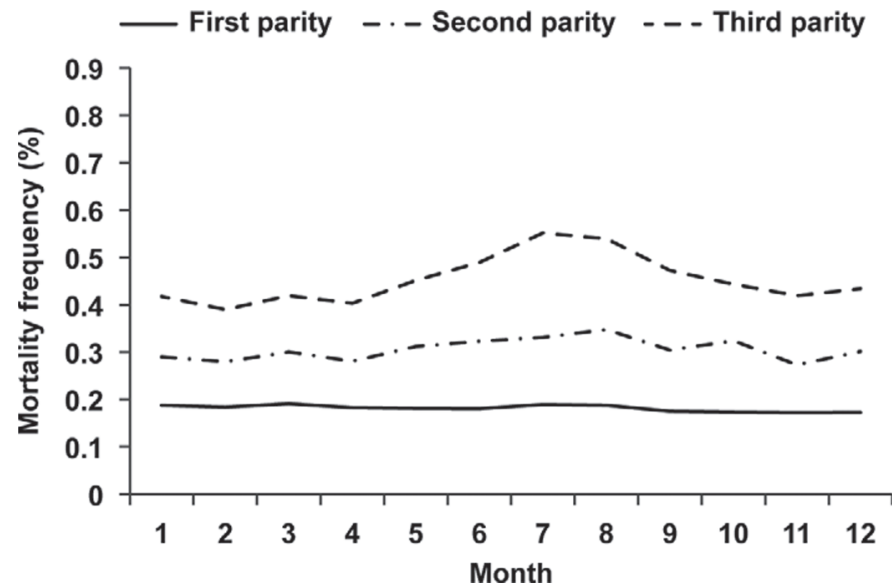

Figure 3. Monthly mortality frequencies for 3 parities in the Northeast region of the United States.

of cows with clinical mastitis. Examination of SCC by states from DHI herds from years 2004 to 2008 (USDAAIPL, 2005-2009) show that states included in the SE region, as defined in the current study, generally had a higher average SCC per herd and a higher percentage of herds with $>750,000$ somatic cells/mL, so perhaps some of the difference between regions could be associated with higher amounts of mastitis in SE herds compared with other regions. Other herd characteristics that are associated with cow mortality and that differ between regions could be examined and quantified in future studies.

The mortality difference between the SE region and the other regions appeared to be the largest during the summer months. As Figures 1, 2, and 3 indicate, the months across most of the parities, particularly in the SE, that had the highest mortality risks were July and August. Miller et al. (2008), Vitali et al. (2009), and Pinedo et al. (2010) observed greater death loss during the summer months compared with other seasons. The NE and SW regions had similar trends for mortality even during the summer months, which was surprising because the SW is known for very high temperatures during the summer. Bohmanova et al. (2007) reported temperature and humidity averages by month for Phoenix, Arizona, and Athens, Georgia. Both temperature and humidity remain high (68-75\%) in Athens throughout the summer, whereas in Phoenix, the humidity is below $32 \%$. Because of this low humidity, evaporative cooling systems are more effective in the dry climate typical of the SW compared with the wet climates of the SE. The mortality data from the summer months in the present study suggest that the combination of high heat and high humidity that occurs in the SE puts cows under much more stress than the high heat and low humidity encountered in the SW.

\section{Variance Components and Heritability for Mortality and 305-d Milk Yield}

Additive genetic variances for mortality were similar for all regions and parities, ranging from 0.05 to 0.09 (Table 2). Herd-year variances for mortality were similar across parity within a region, but regional differences were apparent, with the SW having the largest herd-year variances across parity (0.27 to 0.29$)$ and the $\mathrm{NE}$ having the smallest (0.15 to 0.16). Additive genetic variances for 305-d milk yield varied from $0.33 \times(1,000$ $\mathrm{kg})^{2}$ for the third parity in SE to $0.87 \times(1,000 \mathrm{~kg})^{2}$ for the first parity in NE. The genetic variance decreased as parity increased. The region that had the largest genetic variance for 305-d milk yield was NE, followed by SW, and SE.

Heritability estimates for mortality were low, as expected, ranging from 0.04 to 0.07 across regions and parity. These estimates were similar $(0.01$ to 0.06$)$ to those found by Dematawewa and Berger (1998), who estimated the heritability of first-, second-, and laterparity cows for mortality, milk yield, and several other production and fertility traits using data obtained from MidStates Dairy Records Processing Center (Ames, IA). The region that had the highest heritability for 305-d milk yield was NE, followed by SW and SE. Differences in genetic variances and heritabilities for milk yield were observed across different regions in the United States by Rekaya et al. (2003). In that study, first-parity cows had the highest heritability for milk yield, and heritability decreased as parity increased in all regions.

\section{Correlations Between Mortality and 305-d Milk Yield}

In the current study, a positive residual or genetic correlation estimate indicated that as the environmental effect or genetic effect increased, mortality also increased. The residual correlations between mortality and 305-d milk yield were generally low and positive (0.02 to 0.11 ), indicating that changes in the environment that increased milk production tended to increase the incidence of death in cows.

The genetic correlations between the 2 traits ranged from -0.01 to 0.33 (Table 3 ) and differed across parity within each region and generally indicated that selection for increased milk production will cause increased cow mortality. Dematawewa and Berger (1998) analyzed lactation and survival records from cows located in the US Midwest and reported that the genetic correlations between milk production and cow mortality in the first 2 parities indicated that as milk production increased, mortality increased. They found that the magnitude of the adverse genetic relationship, as indi- 
Table 2. Posterior means (SD) of estimated genetic (G), residual (R), and herd-year (HY) variance components and heritability $\left(\mathrm{h}^{2}\right)$ for $305-\mathrm{d}$ milk yield and mortality in the first 3 parities in 3 regions of the United States

\begin{tabular}{|c|c|c|c|c|c|c|}
\hline \multirow[b]{2}{*}{ Region } & \multicolumn{2}{|c|}{ First parity } & \multicolumn{2}{|c|}{ Second parity } & \multicolumn{2}{|c|}{ Third parity } \\
\hline & $\begin{array}{c}\text { Milk } \\
\times(1,000 \mathrm{~kg})^{2}\end{array}$ & Mortality & $\begin{array}{c}\text { Milk } \\
\times(1,000 \mathrm{~kg})^{2}\end{array}$ & Mortality & $\begin{array}{c}\text { Milk } \\
\times(1,000 \mathrm{~kg})^{2}\end{array}$ & Mortality \\
\hline \multicolumn{7}{|c|}{ Southeast } \\
\hline G & $0.66(0.01)$ & $0.06(0.01)$ & $0.50(0.02)$ & $0.06(0.01)$ & $0.33(0.02)$ & $0.05(0.01)$ \\
\hline $\mathrm{R}$ & $1.70(0.01)$ & 1.00 & $2.11(0.02)$ & 1.00 & $2.24(0.02)$ & 1.00 \\
\hline HY & & $0.21(0.01)$ & & $0.22(0.01)$ & & $0.21(0.01)$ \\
\hline G & $0.79(0.02)$ & $0.08(0.01)$ & $0.50(0.02)$ & $0.09(0.01)$ & $0.41(0.03)$ & $0.08(0.02)$ \\
\hline $\mathrm{R}$ & $1.71(0.02)$ & 1.00 & $2.14(0.02)$ & 1.00 & $2.23(0.03)$ & 1.00 \\
\hline HY & & $0.27(0.02)$ & & $0.29(0.02)$ & & $0.27(0.02)$ \\
\hline $\mathrm{h}^{2}$ & $0.32(0.01)$ & $0.06(0.01)$ & $0.19(0.01)$ & $0.07(0.01)$ & $0.15(0.01)$ & $0.06(0.02)$ \\
\hline \multicolumn{7}{|c|}{ Northeast } \\
\hline G & $0.87(0.01)$ & $0.07(0.01)$ & $0.64(0.01)$ & $0.06(0.01)$ & $0.48(0.01)$ & $0.05(0.01)$ \\
\hline $\mathrm{R}$ & $1.60(0.01)$ & 1.00 & $1.99(0.01)$ & 1.00 & $2.06(0.01)$ & 1.00 \\
\hline
\end{tabular}

cated by the correlation, increased from the first parity to the second parity; however, the genetic relationship was not the same in third and later parities, where the correlation was close to zero. In the current study, the genetic correlation between milk production and cow mortality was positive in the first parity and increased in value (i.e., grew more adverse) in the second parity in both the $\mathrm{SE}$ (0.14 and 0.20) and $\mathrm{NE}$ (0.28 and 0.33); however, the correlation increased again in the SE region (0.29) but decreased slightly in the NE region (0.19). The SW appeared to be different from the other 2 regions, with correlations close to zero for the first 2 parities, followed by an increase in the third parity (0.31).

Overall, it does appear that a moderate adverse genetic relationship exists between milk production and mortality. Even though mortality occurs throughout the year, the summer months are when cows are most prone to die, particularly in the SE, where heat stress is known to occur. A possible topic of future research

Table 3. Posterior means (SD) of genetic and residual correlations between mortality and 305-d milk yield in the first 3 parities in 3 US regions

\begin{tabular}{lrll}
\hline Correlation & $\begin{array}{c}\text { First } \\
\text { parity }\end{array}$ & $\begin{array}{c}\text { Second } \\
\text { parity }\end{array}$ & $\begin{array}{c}\text { Third } \\
\text { parity }\end{array}$ \\
\hline Genetic & & & \\
$\mathrm{SE}^{1}$ & $0.14(0.07)$ & $0.20(0.06)$ & $0.29(0.08)$ \\
$\mathrm{SW}$ & $-0.01(0.08)$ & $0.01(0.08)$ & $0.31(0.06)$ \\
$\mathrm{NE}$ & $0.28(0.04)$ & $0.33(0.04)$ & $0.19(0.05)$ \\
Residual & & & \\
$\mathrm{SE}$ & $0.06(0.01)$ & $0.10(0.01)$ & $0.10(0.01)$ \\
$\mathrm{SW}$ & $0.08(0.01)$ & $0.13(0.01)$ & $0.10(0.01)$ \\
$\mathrm{NE}$ & $0.02(0.01)$ & $0.09(0.00)$ & $0.11(0.01)$ \\
${ }^{1} \mathrm{SE}=$ Southeast & region, SW $=$ Southwest region, NE $=$ Northeast \\
region. &
\end{tabular}

is to determine if the genetic correlation between milk production and mortality becomes more adverse during the summer months, particularly in areas of the United States where heat stress is an issue. Dikmen et al. (2012) reported that the genetic correlation between rectal temperature and milk production in cows was positive. It may be that as the breeding values for milk yield increase, a corresponding increase in body temperature occurs, which could exacerbate the effects of heat stress, leading to increased mortality during the hottest times of the year. Misztal (1999) and Ravagnolo and Misztal (2000) presented a model to estimate heat tolerance genetic values using milk yield records. If sires could be identified that have high genetic values for heat tolerance and milk production using this approach, then these sires might also produce high-milk-yield daughters that are at lower risk for mortality under heat stress conditions. The usefulness of the genetic values predicted using this model should be investigated as a possible way to ameliorate the risk of mortality in high-producing dairy cows that are producing under heat stress conditions. Also, the moderate magnitude of the genetic correlations, if it is constant throughout the year in each region, suggests that indices that include both milk yield and mortality could be effective in increasing milk yield, while possibly reducing death loss.

\section{REFERENCES}

Aguilar, I., I. Misztal, and S. Tsuruta. 2009. Genetic components of heat stress for dairy cattle with multiple lactations. J. Dairy Sci. 92:5702-5711.

Bohmanova, J., I. Misztal, and J. B. Cole. 2007. Temperature-humidity indices as indicators of milk production losses due to heat stress. J. Dairy Sci. 90:1947-1956. 
Bohmanova, J., I. Misztal, S. Tsuruta, H. D. Norman, and T. J. Lawlor. 2008. Genotype by environment interaction due to heat stress. J. Dairy Sci. 91:840-846.

Cole, J. B., P. M. VanRaden, and Multi-State Project S-1040. 2010. Net merit as a measure of lifetime profit: 2010 revision. USDAAnimal Improvement Programs Laboratory Research Report. Accessed Oct. 23, 2013. http://aipl.arsusda.gov/reference/nmcalc. htm\#Expected\%20genetic\%20progress.

Dechow, C. D., R. C. Goodling, and S. P. Rhode. 2012. The effect of sire selection on cow mortality and early lactation culling in adverse and favorable cow survival environments. Prev. Vet. Med. 103:228-233.

Dematawewa, C. M. B., and P. J. Berger. 1998. Genetic and phenotypic parameters for 305-day yield, fertility, and survival in Holsteins. J. Dairy Sci. 81:2700-2709.

Dikmen, S., J. B. Cole, D. J. Null, and P. J. Hansen. 2012. Heritability of rectal temperature and genetic correlations with production and reproduction traits in dairy cattle. J. Dairy Sci. 95:3401-3405.

McConnel, C. S., J. E. Lombard, B. A. Wagner, and F. B. Garry. 2008. Evaluation of factors associated with increased dairy cow mortality on United States dairy operations. J. Dairy Sci. 91:1423-1432.

Miglior, F., B. L. Muir, and B. J. Doormaal. 2005. Selection indices in Holstein cattle of various countries. J. Dairy Sci. 88:1255-1263.

Miller, R. H., M. T. Kuhn, H. D. Norman, and J. R. Wright. 2008 Death losses for lactating cows in herds enrolled in dairy herd improvement test plans. J. Dairy Sci. 91:3710-3715.

Misztal, I. 1999. Model to study genetic component of heat stress in dairy cattle using national data. J. Dairy Sci. 82(Suppl. 1):32. (Abstr.)

Pinedo, P. J., A. De Vries, and D. W. Webb. 2010. Dynamics of culling risk with disposal codes reported by Dairy Herd Improvement dairy herds. J. Dairy Sci. 93:2250-2261.

Ravagnolo, O., and I. Misztal. 2000. Genetic component of heat stress in dairy cattle, parameter estimation. J. Dairy Sci. 83:2126-2130.

Rekaya, R., K. A. Weigel, and D. Gianola. 2003. Bayesian estimation of parameters of a structural model for genetic covariances between milk yield in five regions of the United States. J. Dairy Sci. 86:1837-1844.

SAS Institute. 2008. SAS/STAT User's Guide: Statistics. Version 9.2. Accessed Oct. 17, 2011. http://support.sas.com/documentation/ cdl/en/statug/63033/HTML/default/viewer.htm\#titlepage.htm.

Smith, J. W., L. O. Ely, and A. M. Chapa. 2000. Effect of region, herd size, and milk production on reasons why cows leave the herd. J. Dairy Sci. 83:2980-2987.

Tsuruta, S., and I. Misztal. 2006. THRGIBBS1F90 for estimation of variance components with threshold-linear models. Commun. 27-31 in Proc. 8th World Congr. Genet. Appl. Livest. Prod., Belo Horizonte, Brazil. Instituto Prociencia, Belo Horizonte, Brazil.

USDA-AIPL (Animal Improvement Programs Laboratory). 20052009. Somatic cell counts of milk from Dairy Herd Improvement herds during 2005-2009. Accessed Apr. 11, 2014. https://www. cdcb.us/publish/dhi/scc.html.

USDA-APHIS (Animal and Plant Health Inspection Service). 2007 Dairy 2007 Part II: Changes in the U.S. dairy industry, 19912007. Accessed Oct. 23, 2013. http://www.aphis.usda.gov/animal_ health/nahms/dairy/downloads/dairy07/Dairy07_dr_PartII.pdf.

USDA-APHIS (Animal and Plant Health Inspection Service). 2010 Info Sheet: Mortality of calves and cattle on U.S. beef cow-calf operations. Accessed Oct. 23, 2013. http://www.aphis.usda.gov/ animal_health/nahms/beefcowcalf/downloads/beef0708/Beef0708 is_Mortality.pdf.

USDA-NASS (National Agricultural Statistics Service). 2013. Milk: Production per cow by year, US. Accessed Oct. 23, 2013. http://www.nass. usda.gov/Charts_and_Maps/Milk_Production_and_Milk_Cows/ cowrates.asp.

Vitali, A., M. Segnalini, L. Bertocchi, U. Bernabucci, A. Nardone, and N. Lacetera. 2009. Seasonal pattern of mortality and relationships between mortality and temperature-humidity index in dairy cows. J. Dairy Sci. 92:3781-3790.

West, J. W. 2003. Effects of heat stress on production in dairy cattle. J. Dairy Sci. 86:2131-2144 